\title{
SPAD-502 readings in response to photon fluence in leaves with different chlorophyll content
}

\author{
Helena Cristina Santos Nascimento ${ }^{1}$, Ricardo Antonio Marenco ${ }^{2}$
}

\begin{abstract}
The chlorophyll meter (SPAD-502) is widely used to estimate chlorophyll content, but non-uniform chloroplast distribution can affect its accuracy. This study aimed to assess the effect of photon fluence (F, irradiance $\mathrm{x}$ time of illumination) in leaves with different chlorophyll content and determine the effect of chlorophyll $a / b$ on SPAD values of four tropical tree species (Croton draconoides Müll. Arg., Hevea guianensis Aubl., Hymenaea courbaril L. and Matisia cordata H.B.K.). There were also determined calibration equations for the chlorophyll meter and assessed the effect of F on SPAD values between 07:00 $\mathrm{h}$ and 17:00 h. Calibration equations were obtained after determining leaf chlorophyll content in the laboratory. Increases in $\mathrm{F}$ with time caused a reduction in SPAD values in species with a high chlorophyll content, with reductions of $20 \%$ in $M$. cordata and $10 \%$ in $H$. guianensis. Leaves of $C$. draconoides and $H$. courbaril had lower chlorophyll content and showed no changes in SPAD values with increase in F. The chlorophyll $a / b$ ratio increased with SPAD values and the SPAD/chlorophyll relationship was best described by an exponential equation. It seems that F may affect SPAD values in leaves with high chlorophyll content, probably due to non-uniform chloroplast distribution at high irradiance. This indicates that SPAD values tend to be more accurate if recorded early in morning when irradiance is low.
\end{abstract}

Key words: Accumulated irradiance, chlorophyll, photosynthetic pigments.

\section{RESUMO}

\section{Leituras do SPAD-502 em resposta a fluência de fótons em folhas com diferentes teores de clorofila}

O clorofilômetro (SPAD-502) é amplamente utilizado para estimar teores de clorofila, mas a falta de uniformidade na distribuição dos cloroplastos pode afetar sua precisão. Os objetivos deste estudo foram avaliar o efeito da fluência de fótons ( $\mathrm{F}$ = irradiância $\mathrm{x}$ tempo de iluminação) em folhas com teores diferentes de clorofila e determinar o efeito da relação clorofila $a / b$ nos valores do SPAD em quatro espécies de árvores tropicais (Croton draconoides Müll. Arg., Hevea guianensis Aubl., Hymenaea courbaril L. e Matisia cordata H.B.K.), bem como determinar equações de calibração para o clorofilômetro. O efeito de F nos valores SPAD foi avaliado ao longo do dia, entre 07:00 e 17:00 h. As equações de calibração foram obtidas após determinar laboratorialmente os teores absolutos de clorofila. Aumentos em F causaram uma redução nos valores do SPAD nas espécies com os maiores teores de clorofila, sendo as reduções de $20 \%$ em M. cordata e 10\% em H. guianensis. Folhas das espécies C. draconoides e H. courbaril tiveram menores conteúdos de clorofila e não apresentaram alterações nos valores de SPAD. A relação de clorofila $a / b$ aumentou com

Recebido para publicação em novembro de 2009 e aprovado em agosto de 2010

${ }^{1}$ Bióloga, Mestre. Doutoranda do Instituto Nacional de Pesquisas da Amazônia, Programa de Pós-Graduação em Botânica. Av. André Araújo, 2936, 69060-001, Manaus, AM. Brasil. hc_crys@hotmail.com

2 Engenheiro-Agrônomo, Doutor. Instituto Nacional de Pesquisas da Amazônia, Coordenação de Pesquisas em Silvicultura Tropical. Av. Efigênio Sales, 2239, 69060-020, Manaus, AM. Brasil. rmarenco@inpa.gov.br

Rev. Ceres, Viçosa, v. 57, n.5, p. 614-620, set/out, 2010 
os valores do SPAD e a relação entre valores SPAD/clorofila foi mais bem descrita por uma equação exponencial. F pode afetar os valores do SPAD em folhas com alto conteúdo de clorofila provavelmente em decorrência da desuniformidade na distribuição dos cloroplastos em alta irradiância. Isto indica que os valores do SPAD tendem a ser mais precisos se obtidos logo ao amanhecer, quando a irradiância é reduzida.

Palavras-chave: Irradiância acumulada, clorofila, pigmentos fotossintéticos.

\section{INTRODUCTION}

The photosynthetic pigments, chlorophylls and carotenoids, are by far the most abundant biological pigments on Earth, with a net production of about $1 \mathrm{Pg} \mathrm{yr}^{-1}\left(1 \times 10^{15} \mathrm{~g}\right)$ (Hendry et al., 1987). Besides its importance in harvesting light energy, leaf chlorophyll content is a sensitive indicator of plant stress (Havaux \& Tardy, 1999; Zarco-Tejada et al., 2002), hence, changes in the chlorophyll/carotenoid ratio can be used as indicators of oxidative stress (Magalhães et al., 2009). As there is a close relationship between chlorophyll content and leaf nitrogen concentration, leaf greenness has been used to estimated leaf nitrogen content in several crops, such as maize (Chapman \& Barreto, 1997), coffee (Torres-Netto et al., 2005), and Brachiaria brizantha (Batista \& Monteiro, 2007).

The standard method for determining chlorophyll concentrations is the extraction from leaf tissue and subsequent spectrometric determinations. However, such in vitro measurements are expensive, time consuming and require the destruction of the leaf tissue, which makes impossible to assess the chlorophyll content of a single leaf over time. Another method for measuring leaf greenness, based on the optical properties of the leaf, was developed in the 1980s, whereby the relative chlorophyll content is assessed with a hand held chlorophyll meter, the SPAD-502 (Minolta Corporation, Ltda., Osaka, Japan).

The SPAD-502 measures the transmittance of red light $(650 \mathrm{~nm})$ and infrared radiation $(940 \mathrm{~nm})$ through the leaf and gives out a SPAD reading that is an indicator of the amount of chlorophyll present in the leaf tissue (Minolta, 1989). The main advantage of this method is that many leaf samples can be assessed in a short period of time, so the use of the SPAD 502 has increased exponentially in the last decade. However, some environmental factors such as irradiance (Hoel \& Solhaug, 1998) and soil moisture, and thereby leaf water content (Marenco et al., 2009) may affect SPAD readings. It can be hypothesized that changes in irradiance during the day may affect SPAD readings irrespective of plant species and that SPAD values remain unaltered despite differences in the chlorophyll a/b ratio.
Thus, the primary aim of this study was to assess the effect of photon fluence on SPAD readings of four tropical trees species.

\section{MATERIALS AND METHODS}

The study was conducted at the National Institute for Research in the Amazon (Campus V8) in Manaus, AM, Brazil ( $03^{\circ} 05^{\prime} 30^{\prime \prime}$ S; $\left.59^{\circ} 59^{\prime} 35^{\prime \prime} \mathrm{W}\right)$. The city of Manaus has an average temperature of $26.7^{\circ} \mathrm{C}$, average rainfall of $2260 \mathrm{~mm}$, and a relative humidity of $83 \%$. Tropical tree species growing under full sunlight at the INPA's campus were used in this study. The studied species were: Croton draconoides Müll. Arg. (Euphorbiaceae), Hevea guianensis Aubl. (Euphorbiaceae), Hymenaea courbaril L. (Caesalpiniaceae) and Matisia cordata H.B.K. (Bombacaceae). Selected trees (one per species) were about 1-2 $\mathrm{m}$ in height and 10-20 $\mathrm{mm}$ in diameter (at $0.5 \mathrm{~m}$ above ground), except for $M$. cordata that was $20 \mathrm{~m}$ tall and $0.48 \mathrm{~m}$ in diameter at breast height. For $M$. cordata branches reachable from the ground $(<2 \mathrm{~m})$ were used in the study. The importance of these species is related to latex production ( $H$. guianensis), timber industry $(H$. courbaril), medicinal (C. draconoides) or nutritional properties (M. cordata). Matisia cordata is a fast growing, tropical fruit bearing tree, native to tropical South America. Its fruits, about 12-cm long and $7 \mathrm{~cm}$ diameter, have a high concentration of potassium (similar to those found in banana), but the amount of calcium is almost twice as great as those often reported in the Musaceae family (Leterme et al., 2006). C. draconoides produces a red viscous latex sap known as "dragon's blood" which contains taspine, an alkaloid with medicinal properties (Pieters et al. 1993). Dragon's blood is used by local communities for wound healing and as an anti-inflammatory agent.

To assess the effect of irradiance on SPAD values, chlorophyll meter readings were taken from three fully developed leaves per tree at one hour interval, between 07:00 and 17:00 h. Well-watered trees and leaves with high chlorophyll content as inferred from SPAD readings were used in the experiments. Data on each species were collected from the widest portion of the leaf blade at about $15 \mathrm{~mm}$ from the leaf margin. Data were collected from 30 
May to 22 June 2007 with a SPAD-502 (Minolta Camera Co, Osaka, Japan), positioning the adaxial leaf surface toward the emitting window of the device. Ten readings per leaf (three leaves per plant) were taken from the widest portion of the leaf lamina, while avoiding major veins.

To generate calibration equations SPAD readings were taken early in the morning. Leaves were covered with a plastic bag to avoid dehydration, detached and immediately taken to the laboratory for chlorophyll extraction. Leaves of different developmental stages were used for calibration. Young and very young leaves were used to obtain low chlorophyll content per unit of leaf area. High values of chlorophyll concentration were recorded in fully expanded leaves developed under high irradiance. A mean of 15 leaves (and two samples per leaf) were used at each developmental stage or an average of 45 leaves per plant. Thus, an aggregate of 180 leaves were used to determine the chlorophyll-SPAD relationship.

For chlorophyll extraction, five to ten 5-mm-discs were punched from the same portion of the leaf previously used for SPAD measurements, weighed and immediately ground in aqueous acetone. Then, absorbance (A) was determined at 645 and $663 \mathrm{~nm}$ on a spectrophotometer (SP-2000 UV, Shanghai Spectrum, Shanghai, China).

The solvent ( $2 \mathrm{~mL}$ of distilled water per $8 \mathrm{~mL}$ acetone) was added of $20 \mathrm{mg}$ of $\mathrm{MgCO}_{3}$ (to avoid changes in $\mathrm{pH}$ ) and $50 \mathrm{mg}$ of quartz crystals to facilitate grinding of leaf sample. Chlorophylls were calculated after Arnon (1949):

Chlorophyll $a\left(\mu \mathrm{molm} \mathrm{m}^{-2}\right)=1.119 \times\left[12.7 \mathrm{~A}_{663}-2.69 \mathrm{~A}_{645}\right] \mathrm{V} / \mathrm{L}_{\mathrm{A}}$ Chlorophyll $b\left(\mu \mathrm{molm}{ }^{-2}\right)=1.102 \times\left[22.9 \mathrm{~A}_{645}-4.68 \mathrm{~A}_{663}\right] \mathrm{V} / \mathrm{L}_{\mathrm{A}}$ Where: $\mathrm{V}$ denotes the extract volume $(\mathrm{L}) ; \mathrm{L}_{\mathrm{A}}$, leaf area $\left(\mathrm{m}^{2}\right)$. The constants 1.119 (for chlorophyll $a$ ) and 1.102 (for chlorophyll $b$ ) were used to convert milligrams to micromoles.

Photosynthetic photon flux density (PPFD) data were collected at 15-min-intervals with a $1 \mathrm{~m}$ long line quantum sensor (LI-191 SA, Li-Cor, NE, USA) connected to a dataloger (LI-1400, Li-Cor, NE, EUA). Fluence (F, mol m $\mathrm{m}^{-2}$ ) was calculated as the product of irradiance ( $\mathrm{I}$, in $\mathrm{mol} \mathrm{m} \mathrm{m}^{-2} \mathrm{~s}^{-1}$ ) and time (t, in seconds) of illumination ( $\mathrm{F}=\mathrm{I} \mathrm{x} \mathrm{t}$, in $\mathrm{mol} \mathrm{m}^{-2}$ ). During day time, $\mathrm{F}$ was integrated every $15 \mathrm{~min}$. Special care was taken to assure that the irradiance incident on the leaf surface were similar in magnitude to that recorded by the light sensor, so the line sensor was positioned as close as possible to the monitoring plant. Regression analyses were carried out to examine the effect of photon fluence on SPAD readings and to generate calibration equations. The SAEG 9.0 package of the Federal University of Viçosa-Brazil was used for statistical analysis.

\section{RESULTS}

Maximum PPFD observed during the study period was $960 \mu \mathrm{mol} \mathrm{m} \mathrm{m}^{-2} \mathrm{~s}^{-1}$ at midday, and daily mean $\mathrm{F}$ at sunset was $13.7 \mathrm{~mol} \mathrm{~m}^{-2}$ (Figure 1). Photon fluence did not have any significant effect on SPAD values of $C$. draconoides and $H$. courbaril (Figure 2A-B). However, SPAD readings decreased by about $20 \%$ in $M$. cordata and $10 \%$ in $H$. guianensis in response to $\mathrm{F}$ (Figure 2C-D). It is worth noting that diurnal variation on SPAD readings (Figure 2C-D) were only detected in species with the highest chlorophyll content, that is, in $H$. guianensis and $M$. cordata, which had a chlorophyll $(a+b)$ content of 560 and $730 \mu \mathrm{mol} \mathrm{m}{ }^{-2}$ (Figure 3 ).

Maximum chlorophyll contents (amount of pigments per unit leaf area) were $700 \mu \mathrm{mol} \mathrm{m} \mathrm{m}^{-2}$ for chlorophyll $a$ and $350 \mu \mathrm{mol} \mathrm{m}{ }^{-2}$ for chlorophyll $b$ (Figure 3A-B). Although data fitted to a linear model produced regression coefficients as high as those obtained with the curvilinear model (Table 1, Figure 3A-C), the straight line model overestimated the chlorophyll content at intermediate SPAD values and in some species (Figure 3A-C, H. courbaril, H. guianensis, and $M$. cordata). Whereas, the exponential model often predicted positive chlorophyll contents at very low or nil SPAD values (as expected), the linear model predicted an unrealistic negative chlorophyll content at a zero SPAD values (Table 1 ). The chlorophyll $a / b$ ratio was positively correlated $(p<0.05)$ with the SPAD values (Figure 3D, Table 2 ) when fully expanded leaves from sunny environments were used to obtain the greatest chlorophyll concentrations in the leaf tissue, the only exception was $H$. courbaril.

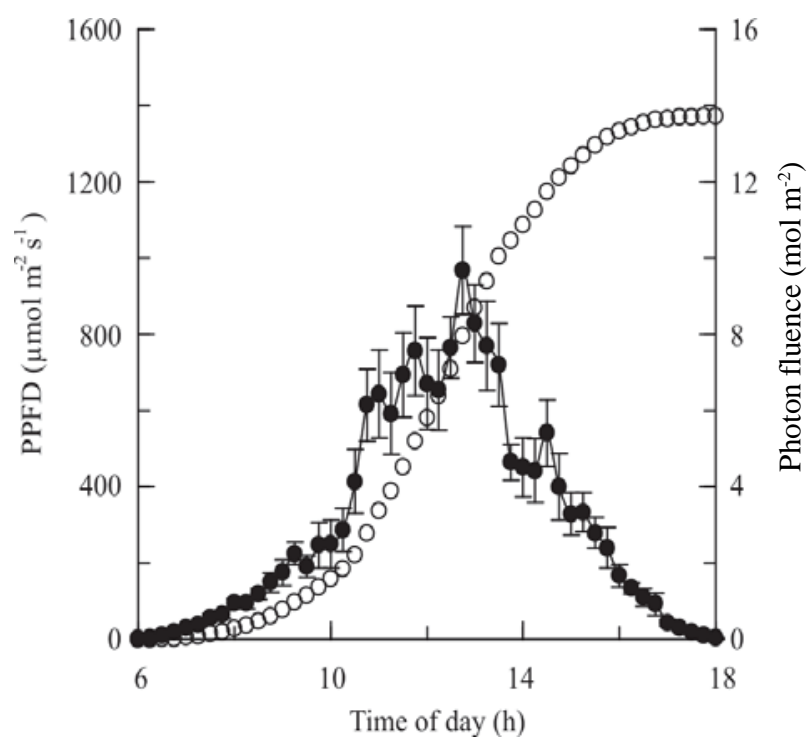

Figure 1. Photon fluence (o) and photosynthetic photon flux density (PPFD) (•) as a function of time. Photon fluence was integrated every $15 \mathrm{~min}$. 


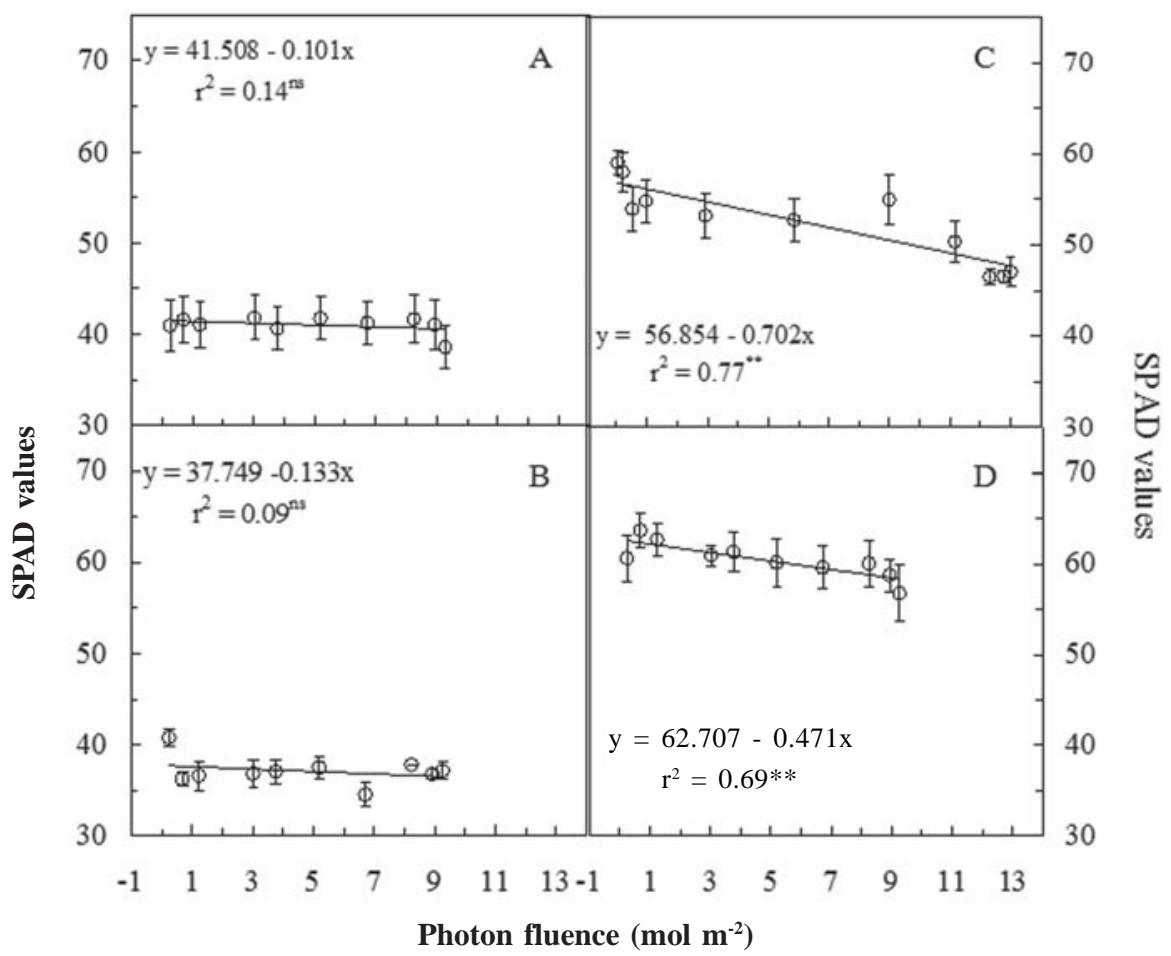

Figure 2. Relationship between photon fluence and SPAD values in Hymenaea courbaril (A), Croton draconoides (B), Matisia cordata (C) and, Hevea guianensis (D). **: highly significant $(p<0.01)$ and ns: not significant. The vertical line on each symbol denotes the standard error.

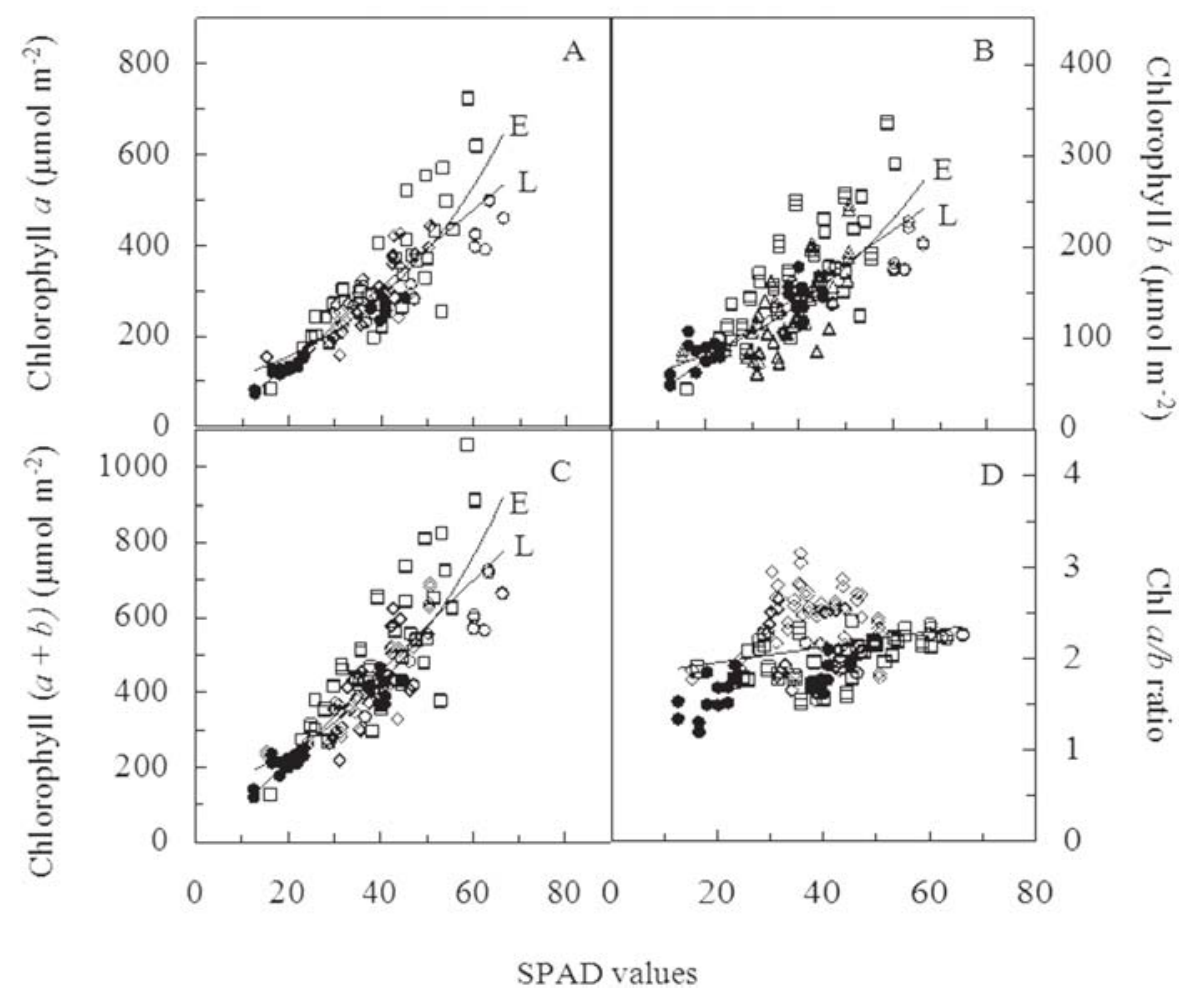

Figure 3. Chlorophyll content and the chlorophyll (Chl) $a / b$ ratio as a function of SPAD values in Hevea guianensis (circle, $\bigcirc \mathrm{n}=$ 20), Matisia cordata (square, $\square \mathrm{n}=63$ ), Hymenaea courbaril (diamond, $\diamond \mathrm{n}=77$ ) and Croton draconoides (solid circle, $\bigcirc \mathrm{n}=23$ ). In panels A-C exponential (E) and linear ( $\mathrm{L}$ ) regression lines are shown to illustrate that observed values (all species pooled together) are better described by an exponential equation, particularly at low and high SPAD values. In panel $\mathrm{D}$, the regression line describes the chlorophyll $a / b$ - SPAD ratio for all species combined; n: number of leaves used per plant. 
Table 1. Linear (L) and exponential (E) calibration equations to convert SPAD readings into absolute chlorophyll content per unit leaf area $\left(\mu \mathrm{mol} \mathrm{m} \mathrm{m}^{-2}\right)$

\begin{tabular}{|c|c|c|c|c|}
\hline Species & & Chlorophyll $a$ & Chlorophyll $b$ & Chlorophyll $(a+b)$ \\
\hline $\begin{array}{l}\text { H. courbaril } \\
(\mathrm{n}=77)\end{array}$ & $\begin{array}{l}\mathrm{L} \\
\mathrm{E}\end{array}$ & $\begin{array}{l}y=-40.79+7.99 x\left(\mathrm{r}^{2}=0.73^{* *}\right) \\
y=75.15 \mathrm{e}^{0.03 x}\left(\mathrm{r}^{2}=0.76^{* *}\right)\end{array}$ & $\begin{array}{l}y=-12.06+3.35 x\left(r^{2}=0.46^{* *}\right) \\
y=36.61 \mathrm{e}^{0.03 x}\left(\mathrm{r}^{2}=0.45^{* *}\right)\end{array}$ & $\begin{array}{l}y=-52.81+11.35 x\left(r^{2}=0.67^{* *}\right) \\
y=112.24 \mathrm{e}^{0.03 x}\left(\mathrm{r}^{2}=0.68^{* *}\right)\end{array}$ \\
\hline $\begin{array}{l}\text { C. draconoides } \\
(\mathrm{n}=23)\end{array}$ & $\begin{array}{l}\mathrm{L} \\
\mathrm{E}\end{array}$ & $\begin{array}{l}y=4.28+5.71 x\left(\mathrm{r}^{2}=0.96^{* *}\right) \\
y=54.51 \mathrm{e}^{0.04 x}\left(\mathrm{r}^{2}=0.94^{* *}\right)\end{array}$ & $\begin{array}{l}y=22.97+2.71 x\left(r^{2}=0.79^{* *}\right) \\
y=41.81 \mathrm{e}^{0.03 x}\left(\mathrm{r}^{2}=0.79^{* *}\right)\end{array}$ & $\begin{array}{l}y=27.25+8.42 x\left(r^{2}=0.92^{* *}\right) \\
y=96.15^{\mathrm{e} 0.03 x}\left(\mathrm{r}^{2}=0.91^{* *}\right)\end{array}$ \\
\hline $\begin{array}{l}\text { H. guianensis } \\
(\mathrm{n}=20)\end{array}$ & $\begin{array}{l}\mathrm{L} \\
\mathrm{E}\end{array}$ & $\begin{array}{l}y=-59.64+7.14 x\left(\mathrm{r}^{2}=0.92^{* *}\right) \\
y=89.12 \mathrm{e}^{0.023 x}\left(\mathrm{r}^{2}=0.94^{* *}\right)\end{array}$ & $\begin{array}{l}y=34.97+2.23 x\left(\mathrm{r}^{2}=0.69^{* *}\right) \\
y=66.43 \mathrm{e}^{0.01 x}\left(\mathrm{r}^{2}=0.67^{* *}\right)\end{array}$ & $\begin{array}{l}y=-24.67+9.37 x\left(r^{2}=0.88^{* *}\right) \\
y=153.32 \mathrm{e}^{0.02 x}\left(\mathrm{r}^{2}=0.90^{* *}\right)\end{array}$ \\
\hline $\begin{array}{l}\text { M. cordata } \\
(\mathrm{n}=63)\end{array}$ & $\begin{array}{l}\mathrm{L} \\
\mathrm{E}\end{array}$ & $\begin{array}{l}y=-66.05+9.12 x\left(\mathrm{r}^{2}=0.67^{* *}\right) \\
y=74.90 \mathrm{e}^{0.03 x}\left(\mathrm{r}^{2}=0.71^{* *}\right)\end{array}$ & $\begin{array}{l}y=-2.05+3.87 x\left(r^{2}=0.59^{* *}\right) \\
y=46.18 \mathrm{e}^{0.03 x}\left(\mathrm{r}^{2}=0.61^{* *}\right)\end{array}$ & $\begin{array}{l}y=-68.09+12.99 x\left(r^{2}=0.66^{* *}\right) \\
y=120.84 \mathrm{e}^{0.03 x}\left(\mathrm{r}^{2}=0.69^{* *}\right)\end{array}$ \\
\hline
\end{tabular}

**: highly significant $(p<0.01)$, n: number of leaves used to generate each equation.

Table 2. Regression equations for the relationship between chlorophyll $a / b$ ratio and SPAD readings

\begin{tabular}{lll}
\hline Species & Equation & $\mathbf{r}^{2}$ \\
\hline Hymenaea courbaril & $y=2.127+0.006 x$ & $\mathrm{r}^{2}=0.02^{\mathrm{ns}}$ \\
Matisia cordata & $y=1.630+0.008 x$ & $\mathrm{r}^{2}=0.17^{* *}$ \\
Hevea guianensis & $y=1.249+0.016 x$ & $\mathrm{r}^{2}=0.53^{* *}$ \\
Croton draconoides & $y=1.310+0.012 x$ & $\mathrm{r}^{2}=0.43^{* *}$ \\
All species & $y=1.786+0.008 x$ & $\mathrm{r}^{2}=0.06^{* *}$ \\
\hline
\end{tabular}

** Highly significant $(p<0.01)$ and ns: not significant $(p>0.05)$.

\section{DISCUSSION}

Mean maximum PPFD values reported in this study are lower than expected under cloud-free sky conditions, about $2000 \mu \mathrm{mol} \mathrm{m}{ }^{-2} \mathrm{~s}^{-1}$. This can be attributed to the fact that data for this research were collected during days when cloudy conditions prevailed during most part of the day, which is not uncommon in Central Amazonia. Perhaps for this reason, these PPFD values are similar to those reported by Dias (2009), who, at the top of a 40-m tall tower in Central Amazonia, observed a mean maximum PPFD of about $1000 \mu \mathrm{mol} \mathrm{m} \mathrm{m}^{-2} \mathrm{~s}^{-1}$. On the other hand, the daily photon fluence recorded in this study $\left(14 \mathrm{~mol} \mathrm{~m}^{-2}\right)$ is only about $50 \%$ of that recorded in the open by Ribeiro et al. (1982). This discrepancy was attributed to the low maximum PPFD values (due to cloudy conditions) and also to the fact that plants used in the study were, both in the morning and the afternoon, under the shadow of neighboring trees, which ultimately led to a decrease in accumulated irradiance.

There was found that in species (M. cordata and $H$. guianensis) with higher chlorophyll content, SPAD readings decreased during the day, whereas in those species with a lower chlorophyll content SPAD values did not show diurnal variation.

It has been found that leaf water content interferes with SPAD readings (Marenco et al., 2009). However, in this study, the changes in SPAD values were not associated with variation in leaf water content because in these experiments well-watered plants were used. Thus, the diurnal changes in SPAD values were attributed to non-uniform chlorophyll distribution, most likely due to chloroplast movements during daytime.

The effect of photon fluence on SPAD values is consistent with the fact that at high chlorophyll content, non-uniform distribution of chlorophyll tends to affect SPAD readings more strongly, while no effect of chlorophyll distribution is expected to be observed at low chlorophyll content (Uddling et al., 2007). This could explain why species with less chlorophyll molecules on the leaf lamina (e.g. Croton draconoides and Hymenaea courbaril) did not respond to changes in light intensity during the day.

Many factors may lead to a lack of linearity in the SPAD-chlorophyll relationship, including a non-uniform distribution of chlorophyll molecules and multiple scattering in an intact leaf (Monje \& Bugbee, 1992; Markwell et al., 1995; Uddling et al., 2007), and because light is absorbed by chlorophylls following the LambertBeer's law. The law states that the amount of incident light $\left(I_{L}\right)$ absorbed (A), as it passes through a sample, is proportional to the concentration of that sample and its thickness (path length) which finally determines the amount of transmitted light $\left(\mathrm{L}_{\mathrm{T}}\right.$; i.e.: $\left.\mathrm{A}=\log \mathrm{I}_{\mathrm{L}} / \mathrm{L}_{\mathrm{T}}\right)$. The classic work by Monsi \& Saeki (1953) also showed that light is exponentially attenuated by leaves and approximately follows the Lambert-Beer's law.

Non-uniform distribution of chlorophyll may lead to variation in SPAD readings due to changes in irradiance 
(Hoel \& Solhaug, 1998; Martinez \& Guiamet, 2004), as at low irradiance the chloroplasts tend to orient toward the periclinal walls, thereby maximizing light absorption, whereas at high-intensity light they may gather at the anticlinal walls where light absorption is minimal (Haupt, 1982). This light-oriented movement may lead to nonuniform chlorophyll distribution and thereby to a nonlinear chlorophyll-SPAD relationship.

In the majority of species (the exception was $C$. draconoides), fitting data to a linear equation unrealistically yielded negative chlorophyll content when the SPAD reading is zero. In addition, in all species, the linear model underestimated the chlorophyll content at high SPAD values. These facts make the exponential equation more reliable particularly when the SPAD readings are either rather low or quite high.

The positive intercept predicted by the exponential model at very low SPAD values is in agreement with the results reported by others (Markwell et al., 1995; Uddlings et al., 2007). The positive intercept could be explained by a stronger absorbance of chlorophyll $b$ at $650 \mathrm{~nm}$ in combination with a relatively high chlorophyll $b$ content at low SPAD values. This hypothesis is supported by a significant lower chlorophyll $a / b$ ratio at low SPAD readings (Figure 3D). A high chlorophyll $a / b$ ratio in fully expanded leaves from sunny environments is in agreement with results reported by Magalhães et al., (2009). A high chlorophyll $a / b$ ratio occurs because of a relatively low amount of light-harvesting complex of photosystem 2 (LHCII) in sun leaves, since most chlorophyll $b$ is associated with LHCII (Hikosaka \& Terashima, 1995). At either too low or too high SPAD values chlorophyll content was underestimated by the straight line model, whereas it was overestimated at intermediate SPAD readings (Figure 3). This can be attributed to multiple scattering (at low chlorophyll content) or non-uniform chlorophyll distribution at high chlorophyll content. A non-uniform chlorophyll distribution across the leaf lamina results in lower SPAD values in comparison with leaves with chlorophyll molecules uniformly distributed (Uddling et al., 2007).

On the other hand, multiple scattering (the reflection and refraction of absorbed radiation that occurs in intercellular spaces) may contribute to the SPADchlorophyll deviation from linearity, as it increases the amount of radiation absorbed (Richter \& Fukshansky, 1996). However, the scattering effect on the SPADchlorophyll relationship is considered to be less important than that caused by a non-uniform chlorophyll distribution, except at low or very low chlorophyll content, as scattering increases as leaf absorptance declines (Uddling et al., 2007). Thus, the loss of linearity found in this study, may be the result of non-uniform chlorophyll distribution at high chlorophyll content and multiple scattering at low chlorophyll content. Finally it should be noted that determination coefficients $\left(\mathrm{r}^{2}\right)$ were higher for the chlorophyll $a$-SPAD relationship than for equations fitted for chlorophyll $b$ values, which suggests that the chlorophyll meter more accurately reflects the chlorophyll $a$ content of a leaf.

\section{CONCLUSIONS}

It can be concluded that photon fluence is an important factor that should be taken into account when the chlorophyll meter is to be used in leaves with high chlorophyll content. This indicates that SPAD values tend to be more accurate if recorded early in morning when irradiance is low. Even when the straight-line model produces similar regression coefficients than the curvilinear one, the latter appears to be more appropriate for fitting chlorophyll concentration as a function of SPAD readings. As $\mathrm{r}^{2}$ values were higher for the chlorophyll $a$ SPAD relationship, it seems that the SPAD-502 more efficiently detects chlorophyll $a$ concentration of leaves.

\section{ACKNOWLEDGEMENTS}

This research was supported by MCT/INPA and FAPEAM (PIPT 1746-08). The authors thank FAPEAM and CNPq for scholarships.

\section{REFERENCES}

Arnon DI (1949) Copper enzymes in isolated choroplasts: Polyphenoloxidase in Beta vulgaris. Pant Physiology, 24:1-5.

Batista K \& Monteiro FA (2007) Nitrogen and sulphur in marandu grass: Relationship between supply and concentration in leaf tissues. Scientia Agricola, 64:44-51.

Chapman SC \& Barreto HJ (1997) Using a chlorophyll meter to estimate specific leaf nitrogen of tropical maize during vegetative growth. Agronomy Journal, 89:557-562.

Dias DP (2009) Fotossíntese e crescimento em diâmetro de árvores em função da temperatura e da precipitação numa floresta primária de terra-firme na Amazônia Central. Tese de Doutorado. Ciências de Florestas Tropicais - Instituto Nacional de Pesquisas da Amazônia (CFT-INPA), Manaus. 123p.

Haupt W (1982) Light-mediated movement of chloroplasts. Annual Review of Plant Physiology, 33:205-233.

Havaux M \& Tardy F (1999) Loss of chlorophyll with limited reduction of photosynthesis as an adaptive response of Syrian barley landraces to high-light and heat stress. Australian Journal of Plant Physiology, 26:569-578.

Hendry GAF, Houghton JD \& Brown SB (1987). The degradation of chlorophyll: a biological enigma. New Phytologist, 107: 255-302.

Hikosaka K \& Terashima I (1995) A model of the acclimation of photosynthesis in the leaves of $\mathrm{C}_{3}$ plants to sun and shade with respect to nitrogen use. Plant, Cell and Environment, 18:605-618.

Hoel BO \& Solhaug KA (1998) Effect of irradiance on chlorophyll estimation with the Minolta SPAD-502 leaf chlorophyll meter. Annals of Botany, 82:389-392. 
Leterme P, Buldgen A, Estrada F \& Londoño AM (2006) Mineral content of tropical fruits and unconventional foods of the Andes and the rain forest of Colombia. Food Chemistry, 95: 644-652.

Magalhães NS, Marenco RA \& Mendes KR (2009) Aclimatação de mudas de acariquara à alta irradiância. Pesquisa Agropecuária Brasileira, 44:687-694.

Marenco RA, Antezana-Vera S \& Nascimento HCS (2009) Relationship between specific leaf area, leaf thickeness, lea water content and SPAD-502 readings in six Amazonian tree species. Photosynthetica, 47:184-190.

Markwell J, Osterman JC \& Mitchell JL (1995) Calibration of the Minolta SPAD-502 leaf chlorophyll meter. Photosynthesis Research, 46:467-472.

Martinez DE \& Guiamet JJ (2004) Distortion of the SPAD 502 chlorophyll meter readings by changes in irradiance and leaf water status. Agronomie, 24:41-46.

Minolta Camera Co. Ltda. (1989) Manual for chlorophyll meter SPAD-502. Minolta Radiometric Instruments divisions, Osaka.

Monje OA \& Bugbee B (1992) Inherent limitations of nondestructive chlorophyll meters: a comparison of two types of meters. Hortscience, 27:69-71.

Monsi M \& Saeki T (1953) Uber den Lichtfaktor in den Pflanzengesellschaften und seine Bedeutung fur die Stoffproduktion (Sobre o fator luz em comunidades vegetais e sua importância na produção de biomassa). Japanese Journal of Botany 14: 22-52.
Pieters L, Bruyne T, Claeys M, Vlietinck A, Calomme M \& Vanden Berghe D (1993) Isolation of a dihydrobenzofuran lignan from South American dragon's blood (Croton spp.) as an inhibitor of cell proliferation. Journal of Natural Products, 56: 899-906.

Ribeiro MNG, Salati E, Nova NAV \& Demetrio CGB (1982) Radiação solar disponível em Manaus (AM) e sua relação com a duração do brilho solar. Acta Amazonica, 12:339-346.

Richter T \& Fukshansky L (1996) Optics of a bifacial leaf: 2. Light regime as affected by the leaf structure and the light source. Photochemistry and Photobiology, 63:517-527.

Torres Netto A, Campostrini E, Oliveira JG \& Bressan-Smith RE (2005) Photosynthetic pigments, nitrogen, chlorophyll a fluorescence and SPAD-502 readings in coffee leaves. Scientia Horticulturae, 104:199-209

Uddling J, Gelang-Alfredsson J, Piikki K \& Pleijel H (2007) Evaluating the relationship between leaf chlorophyll concentration and SPAD-502 chlorophyll meter readings. Photosynthesis Research, 91:37-46.

Zarco-Tejada PJ, Miller JR, Mohammed GH, Noland TL \& Sampson PH (2002) Vegetation stress detection through chlorophyll $a+b$ estimation and fluorescence effects on hyperspectral imagery. Journal Environmental Quality, 31:14331441. 